\title{
TRANSLATION TECHNIQUES REVISITED: THE APPLICABILITY OF EXISTING SOLUTIONS IN NON-LITERARY TRANSLATION
}

\author{
UDC 81'25
}

\author{
Jasmina P. Đorđević \\ University of Niš, Faculty of Philosophy, Niš, Serbia
}

\begin{abstract}
Translation studies have evolved to the extent that phenomena, problems and aspects related to translation are analysed and defined within the discipline itself based on methods and techniques specifically developed for it. One of the many achievements is that two separate translation genres have been identified, i.e. literary and nonliterary translation, followed by different approaches to both theoretical explorations of the two, as well as practical solutions in the process of translating them. The aim of this article is to contribute to the study of non-literary translation by offering an overview of translation techniques available in the literature but not yet distinctly related to nonliterary translation. Since recent approaches to the study of translation imply a strong focus on the target text as a product, the techniques illustrated here are supported by examples originating from an authentic corpus of non-literary translation compiled during twenty-two years of officially recognized translation.
\end{abstract}

Key words: non-literary translation, translation techniques, process, product.

\section{INTRODUCTION}

Translation as an activity originated in ancient times, and it is probably as old as humanity. However, translation as an academic field of research had to wait for the second half of the twentieth century to be recognized and established as an individual scientific discipline (Baker 1992; Baker and Saldanha 2009; Bassnett 2013, 2014; Catford 1965; Gentzler 2001; Munday 2016; Newmark 1982; Nida 1964; Pym 1992; Snell-Hornby 1988, 2006; Toury 1985, 2012). Significant evidence can be found in the literature supporting the fact that systemic linguistic-oriented studies of translation appeared during the first half of the $20^{\text {th }}$ century (cf. Bedson and Schulz 2015; Munday 2016; Pym and Ayvazyan 2015). However, the Second Congress of Slavists in Moscow

Submitted January $10^{\text {th }} 2017$, accepted for publication February $24^{\text {th }}, 2017$

Corresponding author: Jasmina P. Đorđević

University of Niš, Faculty of Philosophy, Niš, Serbia

E-mail: jasmina.djordjevic@filfak.ni.ac.rs 
in 1958 has been accepted as a crucial event determining the further development of translation studies as an academic discipline (Holmes 1988; Snell-Hornby 2006; Toury 1985). At the Congress, the debate referring to linguistic and literary approaches to translation resulted in the proposal to have a separate discipline, outside either linguistics or literature, which would focus on various forms of translation within its own system and based on methods and approaches clearly designed for the purpose of studying translation.

Although the next decade provided translation studies with the work of influential authors, Nida (1964) and Catford (1965) being the most important ones, it was not until the Third International Congress of Applied Linguistics in Copenhagen in 1972 that translation studies were actually recognized as an academic discipline. In one of the most important presentations at the Congress, Holmes (1972) proposed the first classification of academic activities within translation studies. The author himself labelled this attempt as an empirical 'disciplinary utopia', describing the impediments in the way of its development (Holmes 1987: 11). Nowadays, Holmes's contribution is believed to be a visionary blueprint of the future discipline (Snell-Hornby 2006: 54). The classification was presented in the form of a map, available in two expanded versions, both published posthumously in the late 1980s, the first in Holmes (1988) and the second in Toury (1987). It is the second version that is now being quoted by most authors (Fig. 1) as the first structured attempt providing the young discipline with firm scientific grounds to base its further development on.

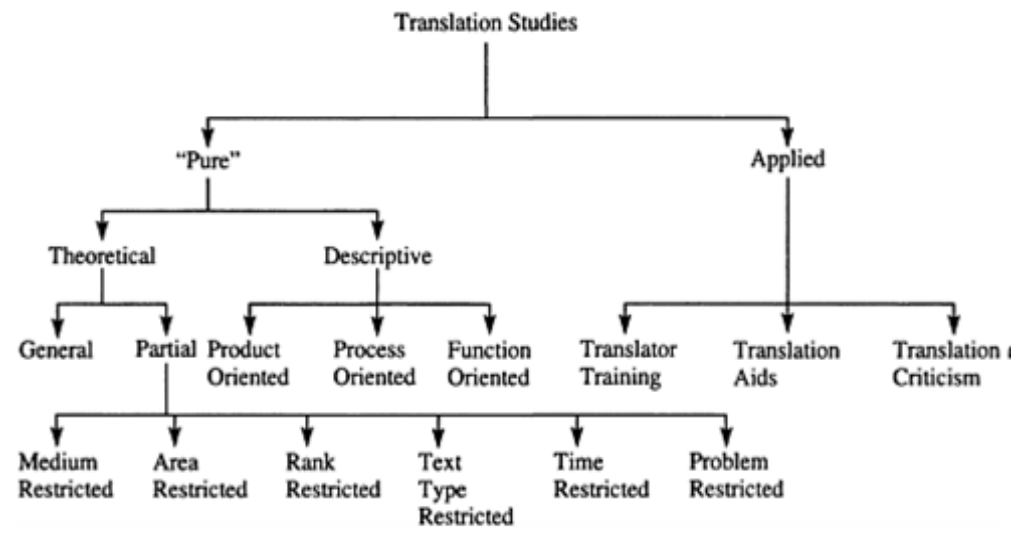

Fig. 1 Holmes's classification of translation studies (Baker and Saldanha 2009: 278)

Yet another major contribution Holmes made to translation studies is that he asked for cooperation between translation theorists and practising translators, as well as between different scholars and schools (Holmes 1988: 101). It goes without saying that support for this plea for interdisciplinary teamwork can be found in the present as well, now probably more than ever since linguistics is undoubtedly expressing both a strong tendency and a general need for interdisciplinary research. Various phenomena, problems and aspects occurring in linguistics in general, may be investigated from different points 
of view (Bassnett 2013; Snell-Hornby 2006; Toury 2012). As a result, especially during the last two decades, problems investigated within related linguistic disciplines have been transferred into the field of translation studies in order to provide new insight concerning those same problems but from the point of view of translation within a discipline of its own (Munday 2016; Snell-Hornby 2006; Toury 2012).

Unfortunately, significant opposition can still be felt among linguists who tend to relate many aspects of translation to the domain of contrastive and comparative linguistics (Bassnett 2013) despite the fact that considerable effort has been invested in separating translation studies from comparative literature and applied linguistics (Bassnett 2013: 4). Only now, with the new millennium underway, do translation studies seem to have been given the recognition they deserve (Snell-Hornby 2006:165) as many practical aspects of translation are now being investigated within the discipline of translation studies based on methodologies and research techniques developed for the purpose of translation (Toury 2012: 13).

In brief, one of the most important steps forward within the discipline, both in theory and in practice, is the recognition of the fact that the translation of literary and nonliterary texts have to be investigated separately. Moreover, different methods, techniques and strategies have to be applied in the investigations of each genre which is why more details, regarding the translation of non-literary texts in particular, will be presented in the following section.

\subsection{Non-literary text in modern translation}

Non-literary and literary texts, as two distinct genres or text types, may be differentiated in the sense that non-literary texts refer to a specific class of texts characteristic of a given scientific community or professional group with certain features of vocabulary, form and style, which are wholly function-specific and conventional in nature (Alcaraz and Hughes 2002: 101). A more detailed analysis of the literature related to non-literary text (Göpferich 2002; Kasper 1997; Kasper and Rose 2001; Leech 1983; Schmidt 1993; Thomas 1983, 2014) reveals that the so-called communicative-pragmatic turn in linguistic studies at the outset of the 1990s started to propose the idea of text being conceived as 'text-in-function', 'text-in-situation' and as a 'socio-communicative functional unit' (Göpferich 2002: 61). Therefore, the term non-literary slowly began to refer to texts which are meant to inform, educate, announce, entertain, illustrate, instruct, present, argue, explain, teach, refer, denote, communicate, etc.

As the aspect of non-literary text being a separate type of text was mentioned more frequently, it was recognized that the difference between translation of fiction vs. translation of factual texts is based on the difference between fiction and factual prose (Fleischmann et al. 1997; Kasper 1997; Munday 2016; Newmark 1998). At first, the latter was referring to scientific discourse only, but in due time, legal texts, maintenance manuals, commercial offers, instructions for domestic appliances, etc. were added to this genre implying that the domain of factual prose is broad and thus deserves to be explored more thoroughly. Therefore, a common feature of factual prose, or non-literary texts, is that their highly pragmatic content requires precision and unambiguous expression as far as style and language are concerned. Accordingly, Newmark (1998) pointed out that in comparison to all other types of translation, the distinction between literary and nonliterary translation is rather clear-cut. Linking literary translation to art and non-literary to 
science, Newmark (1998) introduced the idea that non-fiction (meaning basically informative texts) is concerned with reality and denotations while fiction (referring to artistic texts) is concerned with the imagination and connotations (1998: 63). In a later study, Newmark (2004) pointed out that we can generally talk about the art of literary translation and the science of non-literary translation.

However, with the development of more contemporary approaches to the translation of texts other than fiction, non-literary translation has slowly developed into a label referring to texts covering a wide range of topics including governmental, legal and diplomatic affairs, business administration, scientific research, manuals, commercial offers, advertisements, catalogues, web sites, textbooks, encyclopaedia, film and television scenarios, documentaries, newspaper and magazine articles, news reports, restaurant menus, official letters, etc. (Allen 2007; Baker and Saldanha 2009; Bassnett 2014; Fleischmann et al. 1997; Gawlas 2004; Gibová 2012; Göpferich 2002; Gouadec 2007; Munday 2010; Reiss and Vermeer 1984; Schäffner 2007; Snell-Hornby 2006; Vermeer 1986; Zaytsev 2016). In addition, apart from separating translators of literary and non-literary texts, they are further being separated according to their area of expertise, i.e. the rather distinct fields of knowledge within which they translate, such as law, medicine, diplomacy, engineering, technology, computer science, fashion, etc.

A general conclusion to be drawn at this point is that the translation of non-literary texts may be based on the following premises ${ }^{1}$ :

1. Non-literary translation exists along different lines of discourse and text in comparison to literary translation. This means that a non-literary text has a completely different function, aim and purpose, primarily identified as informative and educational. In comparison to that, a literary text has aesthetic and artistic values meant to evoke emotions and to provide a certain level of entertainment.

2. Formal criteria, such as the style, structure and target audience of the non-literary text in the source language determines the style, structure and target audience of the nonliterary text in the target language. In other words, if a particular text has been written for an audience from a particular academic or scientific field, it should be assumed that the translation of such text will be read primarily by a similar audience.

3. The terminology to be used in the translation of a specific non-literary text must be based on the particular register and terminology used in the respective area in the source language. For instance, the translation of a text related to the area of law and regulations will have to be related to the specific area of law and regulations in the target language.

4. The way a certain non-literary text is perceived in the source language might not necessarily be identical to the way the corresponding text will be perceived in the target language once it has been translated. That is why the particular cultural background and certain way of understanding reality that more or less accompany a non-literary text in the source language will have to be adapted to the cultural background and certain way of understanding reality that the speakers of the target language bring with them when reading the translation.

Given that the study of translation was formally constituted as an individual discipline only a few decades ago (Baker and Saldanha 2009; Holmes 1988; Snell-Hornby 2006;

${ }^{1}$ Further and more specific details regarding non-literary translation in Đorđević (2011a, 2011b). 
Toury 1985), thorough research into the differences between literary and non-literary translation is yet to be realized which is why the distinctions presented in this article should be regarded only as an initial contribution to this aspect within translation studies. In addition, techniques will have to be defined for the purpose of non-literary translation. Until this happens, non-literary translation should rely on existing techniques. That is why the next section of this article will provide a list of established translation techniques that may be applied in the process of translating non-literary text.

\section{TRANSLATION TECHNIQUES REVISITED}

An important aspect of the study of translation has been proposed by Molina and Hurtado (2002) who suggested three categories that may be used in the analysis of a final translation: the text category (dealing with the structure of the text), the context category (dealing with the broader context of the text) and the process category (dealing with the methods, techniques and strategies applied in the translation procedure) (Molina and Hurtado 2002: 489). During the last three decades, a strong focus has been on translation as a product (Baker 1992; Chesterman 1997; Fawcett 2014; Molina and Hurtado 2002; Hatim and Munday 2004; Munday 2009, Toury 1995) as the target text, i.e. the text translated into the target language reveals the detailed procedure the text had been submitted to until the translator offered the final product.

A more detailed review of the available literature focusing on translation techniques shows a number of different classifications, names and definitions regarding both the terms, as well as the types of translation methods, techniques and strategies (Molina and Hurtado, 2002; Munday 2016; Newmark 1988; Nida 1964; Vinay and Darbelnet 1958). In the most general sense, a translation method refers to the approach a translator may take (e.g. literal, idiomatic, free translation, etc.), a technique is a particular solution applied during the translation process when a certain word, phrase or otherwise difficult lexical unit is encountered (e.g. borrowing, calque, modulation, transposition, etc.) and a strategy refers to a certain analytical procedure that a translator may apply when they want to analyse and understand either the source or the target text (e.g. back translation, correspondence analysis, component analysis, paraphrasing, etc.). Translation techniques are most important as they can provide specific solutions for specific problems a translator is confronted with during the process of translation, such as culture-specific terms or terminology related to a certain area of expertise.

With respect to possible classifications of translation techniques, the greatest contribution may be attributed to Vinay and Darbelnet (1958). These two authors offered the first classification of translation techniques with a clear methodological purpose. Other classifications or even new techniques proposed after that, in particular by Nida (1964), Newmark (1988) and Munday (2016), may be considered additional as they expand Vinay and Darbelnet's techniques to elements of culture and specific terminology. For instance, Nida (1964) suggested additions, subtractions and alterations as techniques enabling different forms of adjustment, alteration or adapted expression. Newmark (1988) added recognized translation, functional equivalent, neutralization and translation label. Quite recently, Munday (2016) stressed the importance of experimental translation techniques, such as abusive affinity used to produce a more energetic target text or transcreation applied in contemporary videogame localization. Certain criticism may also 
be found expressing the concern that although certain techniques may be adequate in the case of a particular language pair, they may prove inadequate in the case of a text pair, i.e. the particular area a text belongs to (Molina and Hurtado, 2002).

Despite the expressed criticism and the additional techniques proposed by other authors, Vinay and Darbelnet's techniques are still considered basic and they include: borrowing, calque, literal translation, transposition, modulation, equivalence and adaptation. Apart from these seven basic techniques, Vinay and Darbelnet defined additional techniques, or procedures as they referred to them (Fr. procédés) (Vinay and Darbelnet 1958), the most important ones being: compensation, concentration, dissolution, amplification, economy, reinforcement, condensation, explicitation, implicitation, generalization, particularization and inversion.

All subsequent classifications or new techniques that have been added since the 1960s have again been a result of particular needs and issues occurring within a certain language pair or area of expertise (Molina and Hurtado 2002; Munday 2009). In other words, a particular problem occurring during the translation from a certain source language to a certain target language (or within a specific area of expertise) has most certainly resulted in the use of a specific technique or combination of techniques that may prove useless with another language pair (or area of expertise). Therefore, new techniques defined after Vinay and Darbelnet are very much variations of the ones they initially defined, which does not label the techniques as useless or exclude the possibility of defining new techniques in the future. Translation studies are a growing and expanding discipline, so new solutions may be expected.

In brief, the translation of non-literary texts follows different rules than the translation of literary texts. Many techniques used in literary translation might not be applied in nonliterary translation, and various techniques will be applied within different language pairs and areas of expertise. That is why the next section will be devoted to a number of techniques that are applicable for the purpose of translating non-literary texts from the English to the Serbian language. Any other language pair would have to rely on other techniques, so they will not be mentioned herein.

\subsection{Translation techniques serving the purpose of non-literary texts}

As stated in the previous section, the choice of a particular technique during the process of translation primarily depends on the language pair. In addition, the area of expertise and the specific issue the translator is facing during a particular process of translation may also determine the choice of a certain technique. The following list, provided in alphabetical order, is an attempt to illustrate the most useful techniques for the purpose of translating several types of non-literary texts from English into Serbian. ${ }^{2}$

\section{Adaptation}

This technique may be used when a cultural element in the source language is replaced by a cultural element in the target language, i.e. an element that the speakers of the target language are familiar with. The translator has to research the area that the

\footnotetext{
${ }^{2}$ The examples provided in this section originate from an authentic corpus of non-literary translations compiled by the author during 22 years of practice as an official translator, 12 of which as a sworn translator and interpreter appointed by the Ministry of Justice of the Republic of Serbia.
} 
translation refers to and to provide an expression that matches the meaning of the given context. Examples illustrating adaptation are:

[1] transcript of records - POTVRDA O POLOŽENIM ISPITIMA

[2] certificate of no impediment to marriage - POTVRDA O SLOBODNOM BRAČNOM STANJU

[3] pharmacopoeia - UPUTSTVO ZA IDENTIFIKACIJU LEKOVA

In all the mentioned examples, the provided translations are actually equivalent culture-specific terms. In [1] and [2], the terms belong to the area of administrative procedures and more or less corresponding documents could be found in both the English and the Serbian systems. In [3], the term belongs to the specific area of pharmacy where the term had to be substituted by the name of the document that Serbian pharmacists use.

\section{Amplification}

By means of this technique, the translator adds details that are not present or expressed in the source text but are necessary in the target text so that the recipients of the target text may understand what it is about. For instance:

[4] ... Craig Adams of the Australian Reptile Park told Sydney's Daily Telegraph - ... IZJAVIO JE KREG ADAMS, RADNIK U AUSTRALIJSKOM PARKU REPTILA ZA SIDNEJSKI DNEVNI LIST DEJLI TELEGRAF

[5] gravitationalist - STRUČNJAK ZA PROUČAVANJE GRAVITACIJE

[6] AAPS and its industry collaborator, Breakwater Resources - ISTRAŽIVAČKI CENTAR ADVANCED APPLIED PHYSICS SOLUTIONS (AAPS), KAO I NJIHOV STRATEŠKI PARTNER, BREAKWATER RESOURCES

All the mentioned examples show that quite a number of details had to be added to the equivalents in the target language. In [4], the noun RADNIK (worker) had to be added in the target text to show how Craig Adams is affiliated to the reptile park as it is otherwise impossible to translate the of used in the English source. In [5], the term gravitationalist does not exist in the Serbian language so that the additional detail STRUČNJAK ZA PROUČAVANJE (expert in exploring) was added. In addition transposition was applied (s. technique 5 in this list) whereby the noun gravitationalist standing for the job profile was substituted by the noun GRAVITACIJE standing for the area of study. In [6], not only was the acronym spelt out, but also the additional detail ISTRAŽIVAČKI CENTAR (research centre) was added.

However, if amplification is used in an official translation (e.g. court translation), all personal names and titles, or names of authorities and institutions have to be supplied in their original forms in square brackets following the words and phrases used to translate or transcribe them into the target language (Đorđević 2011b).

\section{Economy}

This technique may be identified as the reverse process of amplification as fewer details are supplied in the target text than are provided in the source text. This technique is more often used in Serbian to English translations, but it may also be useful in English to Serbian translations, such as in the following examples:

[7] the procedure by means of which - POSTUPAK PUTEM KOJEG

[8] in the system of rules which are clearly stipulated in the law - U SISTEMU PRAVILA

JASNO UTVRDENIH ZAKONOM

[9] power of authority - OVLAŠĆENJE 
Examples [7] and [8] show that the case system in the Serbian language may substitute longer phrases in the English language that have to rely on prepositional phrases. Example [9] shows a rather rare case of economy in the language of Serbian administration as one word, OVLAŠĆENJE, is used for various situations in which people involved in some legal or administrative affair have to sign a document empowering a physical person to conduct or handle some business on their behalf and in their name.

4. Borrowing

A very important aspect about borrowing is that it is a rather common topic in contrast and contact linguistics where it is investigated as lexical borrowing and defined as a phenomenon of language occurring when a certain lexical or conceptual gap needs to be filled. Lexical borrowing thus means that a foreign element, i.e. lexical unit is transferred into the native language of a certain group of speakers (Thomason and Kaufmann 1988: 21) whereby one language takes over characteristic structures from another language (Moravcsik 1978: 99). An important aspect of lexical borrowing, as seen from the point of view of contrast and contact linguistics is that the transfer of the foreign element is basically occurring at an unconscious level. In other words, speakers more or less start using a foreign word because they have been exposed to it.

In comparison to that, from the point of view of translation studies, borrowing is a technique that a translator consciously chooses when no other alternative for a lacking translation equivalent seems to be available. ${ }^{3}$ Of course, certain rules have to be obeyed in the process of borrowing when translating from the English into the Serbian language, the most important one being that the rules of phonology and orthography defined in the Serbian language have to be obeyed. Borrowing as a translation technique is considered rather problematic as it may have a negative influence on a target language as a whole. Since the problem of language change is an issue exceeding the scope of this article, at this point, it should be enough to emphasize that borrowing as a technique in translation should be used sparingly and only if all other alternatives have proven inadequate (Đorđević 2008), such as in the following cases of culture-specific terms or scientific discourse:

[10] the player hit another home run - IGRAČ JE POSTIGAO JOŠ JEDAN HOUMRAN

[11] the patients agreed to the pilot project - PACIJENTI SU PRISTALI DA UČESTVUJU U PILOT PROJEKTU

[12] muon tomography - TOMOGRAFIJA UZ PRIMENU MIONA, TO JEST NEGATIVNO NAELEKTRISANIH SUBATOMSKIH ČESTICA

Examples [10] and [11] illustrate the most obvious use of borrowing in translation where an English word has simply been imported into the Serbian language and adapted to the pronunciation and writing system of the Serbian language (HOUMRAN and PILOT PROJEKAT). In [12] the technique of borrowing resulted in TOMOGRAFIJA (tomography) and was then combined with amplification as the more elaborate detail TO JEST NEGATIVNO NAELEKTRISANIH SUBATOMSKIH ČESTICA (i.e. negatively charged subatomic particles) was added in the target language. The justification for the use of amplification may be found in the fact that the procedure mentioned in the source text (тиоп tomography) is relatively new and had not yet been translated into Serbian.

\footnotetext{
${ }^{3}$ More details regarding the importance of equivalence in non-literary translation in Đorđević (2010).
} 


\section{Transposition}

This technique is most often used to substitute a certain class of word with another one in the target language. For instance, a verb may be translated by means of a noun, or an adjective may be used instead of a noun. In addition, transposition may also be used to resolve the lack of correspondence occurring at the level of grammar, syntax and morphemes, such as in the following examples:

[13] You tend to get finer results if you allow the blender to run a little longer - BOLJI

REZULTATI SE POSTIŽU UKOLIKO SE BLENDER OSTAVI DA RADI MALO DUŽE

[14] snoring toddlers - MALA DECA KOJA HRC̆U

[15] the applied earth drilling procedure - PRIMENJENI POSTUPAK BUŠENJA ZEMLJE

[16] unemployment is high on the agenda of the government - NEZAPOSLENOST JE PRIORITET VLADE

Example [13] shows the use of transposition at the level of the whole sentence. Although not common in the Serbian language, the passive voice was chosen in this case to avoid the you used in the English source as the second person singular or plural $(T I / V I)$ is deemed inappropriate in written Serbian. In [14], the use of the present participle as a pre-modifier is common in English, but in Serbian, in this particular case, the correspondent form would be incorrect ( $\left.{ }^{*} H R C \check{C} E \dot{C} A D E C A\right)$. In [15] the compound noun earth drilling procedure was translated by translating the last word (the Head) in the compound first and then the two pre-modifiers, which is a common approach to compounds. Often it is more appropriate to put the second pre-modifier first, such as in this case, POSTUPAK BUŠENJA ZEMLJE. In [16], the translation of the second part of the sentence, high on the agenda of the government, was translated by applying two techniques, transposition and economy. In the first step, the adverbial phrase high on the agenda was translated by means of a noun phrase, PRIORITET VLADE so that the whole part was actually translated based on economy, i.e. with two words only. A literal translation in this case (*VISOKO NA AGENDI VLADE) would be inappropriate.

6. Modulation

Unlike transposition that provides the translator with the possibility to exchange one grammatical category with another, modulation implies that the translator may change the perspective, i.e. the point of view that the recipient of the target text may have. Vinay and Darbelnet (1958) believed that different types of modulation may be identified and that perspectives may be altered depending on the context. For instance, a translator may present abstract as concrete, cause as result, aim as goal, part as whole, etc. In other words, a certain phrase may be presented from a new point of view without changing the meaning. For the purpose of clarification, an already existing translation based on modulation may be illustrated:

[17] the restaurant offers draught beer - U RESTORANU SE NUDI TOČENO PIVO

In [17], draught in the source language refers to the person who actually swallows, i.e. drinks the beer whereas the equivalent TOČENO in the target language refers to the person who serves the beer, i.e. taps or draws it from the barrel.

Similarly, in a more recent translation [18], the point of view was changed in the sense that instead of seeing something as wrong it was presented as NIJE TAČNO (not correct):

[18] this result is wrong - OVO REŠENJE NIJE TAČNO 
Yet another example [19], shows what happens in cases of double negatives which are considered grammatically incorrect in English but in Serbian the use of more than one negative form may be necessary to express a certain point of view:

[19] this type of procedure is not easy at all - OVA VRSTA POSTUPKA NIJE NIMALO LAKA

\section{Compensation}

This technique enables the translator to express a certain stylistic effect that is present in the source text but may not be reproduced in the target text. For instance, compensation may be necessary when translating scientific or academic discourse from English into Serbian. When an author presents their results in a research article, they use either the first person singular or passive sentences. Unlike, that in Serbian academic discourse, the use of the first person plural is considered more appropriate, such as illustrated in the following example.

[20] I extracted the particles by applying - ČESTICE SMO ODVOJILI TAKO ŠTO SMO PRIMENILI

It goes without saying that other techniques may be presented apart from the ones presented here. The abbreviated list presented here should illustrate the most effective techniques that may help a translator resolve a particular issue encountered during a translation procedure. Apart from techniques, a translator may also resort to translation strategies when in need of a certain solution for a term, word or phrase otherwise difficult to translate. Key strategies to be used are those that enable the analysis of both source and target text so as to provide deeper insight into the context of the whole text and the particular meaning of a unit within the specific text. Translators may resort to strategies of language analysis common in other linguistic disciplines, such as contrastive analysis, used in contrastive linguistics, or component analysis, used in semantics. However, translators may resort to strategies developed within the study of translation as well, such as back translation or paraphrasing. Since the scope of this article does not permit any detailed discussion regarding translation strategies, only one aspect shall be highlighted here - a translator will have to resort to various techniques, apply different strategies and learn how to successfully combine different approaches in order to deliver a correct translation.

\section{CONCLUSION}

Translation studies were established as an independent scientific discipline in the second half of the twentieth century. At the Second Congress of Slavists in Moscow in 1958, the necessity for a separate discipline exploring translation outside of either linguistics or literature was recognized and in 1972, at the Third International Congress of Applied Linguistics in Copenhagen, the discipline was established under the name Translation Studies. Two decades later, two distinct translation genres, nowadays known as literary and non-literary translation, were recognized.

This article offers some initial insight into the various translation techniques that may be applied for the purpose of translating non-literary texts. The presented techniques are based on techniques defined by Vinay and Darbelnet in 1958 since their classification of translation techniques was the first one with a clear methodological purpose and is still considered the most valid. Although other attempts at classifying techniques can be 
attributed to other authors, it seems that the ones defined by Vinay and Darbelnet are more or less being expanded in terms of various language pairs or areas of expertise.

Apart from being primarily chosen pursuant to a specific language pair, translation techniques may depend on the area of expertise and the specific issue the translator is facing when translating. The ones presented and discussed in this article are useful for the purpose of translating non-literary texts from English into Serbian. The list includes the following: adaptation, amplification, economy, borrowing, transposition, modulation and compensation. These techniques have been supported by examples from an authentic corpus compiled from official and verified translations, and they have been chosen based on prominent issues regarding certain terminology, culture-specific elements and a particular way of understanding reality that may be related to the recipients of the target text in the target language, i.e. Serbian.

More research into the study of non-literary translation will have to be conducted. One of the most urgent problems includes equivalence and correspondence, especially with regard to terminology and culture-specific elements. In addition, the range of texts that may be labelled as non-literary has yet to be identified and practical solutions are needed for the training of professional non-literary translators in different areas of expertise as well as the recognition of the profession of translation as such. Now that several doors have been opened to the study of non-literary translation, it may be expected that more research will follow.

Acknowledgement: The author would like to express special thanks to the Higher Court in Vranje as well as the judges handling the criminal cases that the author as an official interpreter and translator participated in.

\section{REFERENCES}

Alcaraz Varó, E., Hughes, B. (2002), Legal Translation Explained, St. Jerome, Manchester.

Allen, E. (2007), To Be Translated or not to Be: PEN/IRL Report on the International Situation of Literary Translation, Institut Ramon Llull, Barcelona.

Baker, M. (1992), In Other Words: A Coursebook in Translation, Routledge, London and New York.

Baker, M., Saldanha, G. (2009), Routledge Encyclopedia of Translation Studies, Routledge, London and New York.

Bassnett, S. (2013), Translation, Routledge, London and New York.

Bassnett, S. (2014), Translation Studies (Fourth edition), Routledge, London and New York.

Bedson, T., Schulz, M. (2015), Sowjetische Übersetzungskultur in den 1920er und 1930er Jahren. Die Verlage Vsemirnaja literatura und Academia, Frank \& Timme, Berlin.

Catford, J. C. (1965), A Linguistic Theory of Translation, Longman, London.

Chesterman, A. (1997), Memes of Translation: The Spread of Ideas in Translation Theory, John Benjamins, Amsterdam.

Đorđević, J. (2008), "Semantička uslovljenost srpskog poslovnog jezika" [Semantic Conditioning of the Serbian Business Language], Prevodilac 3-4, Vol. 8: pp. 15-29.

Đorđević, J. (2010), "Equivalence and the cogno-cultural dimension in scientific, professional and official translations", Facta Universitatis, Series: Linguistics and Literature 8, Vol. 1: pp. 35-46.

Đorđević, J. (2011a), "Translation for specific purposes as based on cogno-cultural analysis". In: Ignjacevic, A., Djorovic, D., Jankovic, N., Belanov, M. (eds.) Language for specific purposes: challenges and prospects, Foreign Language and Literature Association of Serbia, Belgrade: pp. 538-546.

Đorđević, J. (2011b), Scientific, professional and official translation; The theory, USEE: Novi Sad.

Fawcett, P. (2014), Translation and Language, Routledge, London and New York.

Fleischmann, E., Kutz, W., \& Schmitt, P. A. (1997), Translationsdidaktik - Grundfragen der Übersetzungswissenschaft, Gunter Narr Verlag, Tübingen. 
Gawlas, C. (2004), Nachrichten - heiser Draht zwischen Lebenswelten. Kulturtransfer im internationalen Pressewesen, Peter Lang, Frankfurt.

Gentzler, E. (2001), Contemporary Translation Theories, Multilingual Matters, Clevedon.

Gibová, K. (2012), Translation Procedures in the Non-Literary and Literary text Compared, Books on Demand, Wisconsin.

Göpferich, S. (2002), Textproduktion im Zeitalter der Globalisierung: Entwicklung einer Didaktik des Wissenstransfers, Studien zur Translation 15, Stauffenburg, Tübingen.

Gouadec, D. (2007), Translation as a Profession (Vol. 73), John Benjamins, Amsterdam.

Hatim, B., Munday, J. (2004), Translation: An Advanced Resource Book, Psychology Press, New York.

Holmes, J. (1972), "The Name and Nature of Translation Studies". Unpublished manuscript. Reprinted in Toury, G. (1987), Translation across Cultures, Bahri Publications, New Delhi.

Holmes, J. (1987), "The Name and Nature of Translation Studies", Indian Journal of Applied Linguistics 13, Vol. 2: pp. 9-24.

Holmes, J. (1988), Translated! Papers on Literary Translation and Translation Studies, Rodopi, Amsterdam.

Kasper, G. (1997), “The Role of Pragmatics in Language Teacher Education”, In: Bardovi-Harlig, K., Hartford, B. S. (eds.) Beyond Methods: Components of Language Teacher Education, McGraw Hill, New York: pp. 113-136.

Kasper, G., Rose, K. R. (2001), Pragmatics in Language Teaching, Ernst Klett Sprachen, Stuttgart.

Leech, G. (1983), Principles of Pragmatics, Longman, London and New York.

Molina, L., Hurtado, A. A. (2002), "Translation Techniques Revisited: A Dynamic and Functionalist Approach", Meta: Journal des traducteurs / Meta: Translators' Journal 47, Vol. 4: pp. 498-512.

Moravcsik, E. (1978), "Language Contact", In: Greenberg, J. (ed.), Universals of Human Language, Stanford University Press, Stanford: pp. 93-122.

Munday, J. (2009), The Routledge Companion to Translation Studies, Routledge, London and New York.

Munday, J. (2010), "Translation Studies", The Year's Work in Critical and Cultural Theory 18, Vol. 1: pp. 221-238.

Munday, J. (2016) Introducing translation studies: Theories and applications, Routledge, London and New York.

Newmark, P. (1982), Approaches to Translation, Pergamon Press, Oxford.

Newmark, P. (1988), A Textbook of Translation, Longman, London.

Newmark, P. (1998), More Paragraphs on Translation, Multilingual Matters, Clevedon.

Newmark, P. (2004), "Non-literary in the Light of Literary Translation", Journal of Specialized Translation 1: pp. 8-13.

Nida, E. A. (1964), Toward a Science of Translating, EJ Brill, Leiden.

Pym, A. (1992), Translation and Text Transfer, Peter Lang, Frankfurt.

Pym, A., Ayvazyan, N. (2015), "The Case of the Missing Russian Translation Theories", Translation Studies 8, Vol. 3: 321-421.

Reiss, K., Vermeer, H. J. (1984), Grundlegung einer allgemeinen Translationstheorie, Niemeyer, Tübingen.

Schäffner, C. (2007), "Politics and Translation", In: Kuhiwczak, P., Littau, K. (eds.) A Companion to Translation Studies, Multilingual Matters. Clevedon: pp. 134-147.

Schmidt, R. (1993), "Consciousness, Learning and Interlanguage Pragmatics”, In: Kasper, G., Blum-Kulka, S. (eds.), Interlanguage Pragmatics. Oxford University Press, New York: pp. 21-42.

Snell-Hornby, M. (1988), Translation Studies. An Integrated Approach. John Benjamins, Amsterdam.

Snell-Hornby, M. (2006), The Turns of Translation Studies: New paradigms or shifting viewpoints? (Vol. 66), John Benjamins, Amsterdam.

Thomas, J. A. (1983), “Cross-Cultural Pragmatic Failure”, Applied Linguistics 4, pp: 91-112.

Thomas, J. A. (2014), Meaning in Interaction: An Introduction to Pragmatics, Routledge, London and New York.

Thomason, S. G., Kaufmann, T. (1988), Language Contact, Creolization and Genetic Linguistics, University of California Press, Berkley and Los Angeles.

Toury, G. (1985), "Aspects of Translating into Minority Languages from the Point of View of Translation Studies", Multilingua: Journal of Cross-Cultural and Interlanguage Communication 4, Vol. 1, pp: 3-10.

Toury, G. (1987), Translation across cultures, Bahri Publications, New Delhi.

Toury, G. (2012), Descriptive Translation Studies and beyond: Revised Edition (Vol. 100), John Benjamins, Amsterdam.

Vermeer, H. J. (1986), "Übersetzen als kultureller Transfer", In: Snell-Hornby, M. (ed.) Übesetzungswissenschaft Eine Neuorientierung. Zur Integrierung von Theorie und Praxis, Francke, Tübingen: pp. 30-53.

Vinay, J. P., Darbelnet, J. (1995), Comparative Stylistics of French and English: A methodology for translation (Vol. 11) John Benjamins, Amsterdam. [Translation and revision of the original: Vinay, J. P., \& Darbelnet, J. (1958), Stylistique comparée du français et de l'anglais, Didier, Paris.]

Zaytsev, A. (2016), A Guide to English-Russian and Russian-English Non-Literary Translation, Springer, Singapore. 


\section{PREGLED PREVODILAČKIH TEHNIKA: PRIMENLJIVOST POSTOJEĆIH REŠENJA ZA POTREBE NEKNJIŽEVNOG PREVOĐENJA}

Nauka o prevođenju se razvila do te mere da se pojave, problemi $i$ aspekti u vezi sa prevođenjem analizirauju i definišu u okviru same discipline na osnovu posebno utvrđenih metoda $i$ pristupa. Jedno od mnogih postignuća je da su utvrđena dva posebna prevodilačka žanra, tj. književno i neknjiževno prevođenje koje prate različiti pristupi kako u odnosu na njihovo teorijsko izučavanje tako i u odnosu na praktična rešenja u samom postupku njihovog prevođenja. Cilj ovog rada je da doprinese izučavanju neknjiževnog prevođenja tako što nudi pregled dostupnih prevodilačkih tehnika koje u literaturi do sada nisu dovođene u vezu sa neknjiževnim prevođenjem. Budući da novija istraživanja u nauci o prevođenju naglasak stavljaju na ciljni tekst kao proizvod, prikazane tehnike potkrepljene su primerima iz autentičnog korpusa neknjiževnih prevoda prikupljanih tokom dvadeset $i$ dve godine zvanično priznatog prevođenja.

Ključne reči: neknjiževno prevođenje, prevodilačke tehnike, postupak, proizvod. 